I Universidade Estadual de Campinas (Unicamp),

Campinas, SP, Brasil

irisndocarmo@gmail.com

Íris Nery do Carmo'

\title{
O PERIGO DAS DOBRAS: \\ ICONOGRAFIAS E CORPORALIDADES NO FEMINISMO CONTEMPORÂNEO
}

Enquanto movimento organizado em torno da contestação das assimetrias de gênero, o feminismo ressurgiu timidamente no Brasil nos anos I970, em meio à luta de oposição ao governo militar. As décadas seguintes assistiram à crescente ampliação do alcance do movimento e ao incremento de suas fileiras. Se com a transição democrática, o feminismo dos anos I980 e I 990 teve, de forma inédita, forte articulação com instituições políticas e organizações não governamentais - buscando assim influenciar políticas públicas ao fazer uso de ferramentas institucionais -, no final da década de I990 começa a tomar corpo o que diversas autoras chamam de "fuga de investimentos" das instituições internacionais (Alvarez, 20I4a, 20I4b; Gonçalves, Freitas \& Oliveira, 20I3; Gonçalves, 20I6). ${ }^{\mathrm{I}}$

Hoje o feminismo brasileiro se caracteriza por intensa pervasividade de seus discursos nos diversos âmbitos da sociedade, assim como pela diversidade de formatos, estratégias e sujeitos ativistas. Como bem sintetizado por Gomes (2016: 43), "se no início dos anos I 980 o campo feminista era bastante circunscrito, hoje ele permeia outros movimentos sociais, a sociedade civil e as instituições políticas, além de cenas culturais e artísticas e o mercado".

Neste artigo apresento questões desenvolvidas a partir de minha pesquisa de doutorado atualmente em curso, a qual diz respeito aos movimentos sociais contemporâneos e aos novos sujeitos políticos, tendo como pano de fundo a reverberante multiplicidade de vozes e sujeitos que se identificam como feministas. 
O trabalho tem como objeto empírico uma rede informal de ativistas que se reconhecem como feministas, têm idades entre 20 e 30 anos, estão em trajetórias universitárias, provindas de camadas médias urbanas e que se articulam em rede, interligando diversos estados do Brasil. Elas se apropriam de referências diversas, tais como o vegetarianismo, o autonomismo, o punk, o direito à cidade e o anarquismo, entre outras, tecendo interlocuções e articulações com outros movimentos e atores sociais. ${ }^{2}$

Tais relações são orientadas por um ideário mais geral cujo léxico diz respeito à autonomia e horizontalidade. Assim, é a orientação política de cunho anarquista/autonomista que parece organizar as adjetivações que são contingentes, intercambiáveis e, às vezes, cumulativas - feministas veganas, feministas libertárias, feministas lésbicas radicais, anarkafeministas, feministas autônomas, feministas punks são algumas dessas possibilidades acionadas no campo etnográfico.

Sendo assim, o interesse analítico recai sobre o fluxo de referências políticas, estilos e categorias os quais se articulam a partir de diversas apropriações, contestações e ressignificações, conformando uma gramática política própria.

A circulação das ativistas entre diversas agendas e bandeiras políticas compõe um pertencimento múltiplo, que dá lugar a um sujeito político feminista cujo repertório vai além das questões relativas a gênero num sentido tradicional. A pesquisa se debruça sobre esse trânsito, a fim de entender a chamada hifenização dos feminismos. Os trânsitos de referências consistem em dinâmica que instiga a revisão crítica de termos amiúde utilizados para fazer menção à crescente diversidade de vozes dentro dos feminismos, como "pluralidade" (Díaz, 20I7), "fragmentação", "segmentação”, “diversificação”, "adjetivação”, "multifacetado" (Kempson, 20I5), "heteroglossia” (Haraway, 2009), "polifonia”, "sidestreamings" (Alvarez, 20I4a; 20I4b) e mesmo "hifenização" (Oliveira, 2010).

Considero tratar-se de agentes relevantes no interior da crescente proliferação de discursos e narrativas em torno do gênero, dos feminismos e da diversidade sexual no Brasil, a partir de forte marcador geracional. Assim, busco também contribuir para a compreensão acerca das formas contemporâneas de politização e contestação de convenções de gênero e sexualidade.

De acordo com a bibliografia, há um marco representado pelos anos 2000 , quando no Brasil vemos surgir grupos e organizações formados por jovens não mais como indivíduos dentro do movimento feminista, mas como ator coletivo cujo pertencimento geracional é um elemento aglutinador. Além de plataformas políticas específicas já postas, como de negras, lésbicas e indígenas, nos anos 2000 outros sujeitos passam a reivindicar visibilidade, como é o caso de mulheres trans, jovens e homens feministas (Adrião \& Toneli, 2008; Adrião, Toneli \& Maluf, 20I I; Kempson, 20I5), conformando um cenário crescentemente polifônico (e conflitivo) onde coexistem diversas temporalidades ativistas.

Não obstante, não existe homogeneidade no chamado feminismo jovem. Há clivagens significativas em termos da relação com partidos políticos, com 
o Estado, com o formal e o informal. É preciso sublinhar também que o pertencimento a determinado grupo etário nem sempre é acompanhado pela assunção da juventude em termos de identidade política - por exemplo, a categoria "jovens feministas" é utilizada sem mais exames por autoras como Oliveira \& Gonçalves (20I6), entre outras. Ainda, é necessário ter cautela a fim de não polarizar a análise entre, de um lado, "jovens criativas" e, de outro, "velhas obsoletas".

Em vez de classificar esse momento pós-anos 2000 como uma "quarta onda", como o fazem autoras como Santos (20I6), Kempson (2015), Melo (2013) e Matos (20I4), estou de acordo com Alvarez (20I4b), que opta por traçar o que chama de "múltiplas genealogias e o desenvolvimento rizomático" dos feminismos latino-americanos. Nesse contexto emergem expressões feministas jovens engajadas em modalidades ativistas não institucionais, uma inflexão especialmente visível a partir de 20 Io (Alvarez, 20 I4a; Facchini \& Rodrigues, no prelo).

Por conseguinte, há um diálogo íntimo com modalidades não institucionais de intervenção política que tem sido objeto de atenção, sobretudo a partir das mobilizações que tomaram as grandes capitais do país desde junho de 2013 e que suscitaram inúmeras questões referentes à ausência de dirigentes e lideranças formais nas chamadas Jornadas de Junho. ${ }^{3}$ É preciso ter cuidado, contudo, ao tomar 2013 como um marco temporal, pois manifestações igualmente significativas na conformação desse repertório ativista, como a Marcha das Vadias, datam de período anterior. Além disso, a reivindicação de autonomia e a recusa a formas institucionalizadas de participação não constituem em si algo inédito, como evidenciam etnografias realizadas no país na década de I980, por exemplo, Gregori (I993) e Macrae (I990). ${ }^{4}$

Nessa pesquisa com abordagem etnográfica, tenho feito trabalho de campo de modo a acompanhar os eventos produzidos pelas interlocutoras, assim como seu trânsito entre outras instâncias do movimentos e formas de engajamento político. Eles consistem não só em momentos de formação política, como de experimentação de novas condutas, de encontros e reatualização das relações entre ativistas. Considerando que se trata de pessoas que viajam e se visitam com frequência no interior de um circuito de eventos, isso tem implicado uma etnografia móvel, realizada em diversas regiões do país, acompanhando a circulação das ativistas.

Os eventos em que tem sido realizada parte significativa da observação participante acontecem principalmente em grandes cidades do país, como São Paulo, Rio de Janeiro, Salvador, Porto Alegre, entre outras - com preponderância do Sudeste. Eles representam pontos nodais em uma espécie de circuito ativista jovem que é móvel e informal (êmicamente referenciado como o rolê). Acontecem em locais públicos, como bibliotecas, universidades e centros de cultura, assim como em estabelecimentos comerciais de entretenimento, como casas 
de show, e seguem uma espécie de roteiro: os eventos começam durante o dia, com performances, rodas de conversa, debates e oficinas, e terminam à noite, com shows de rock, punk, funk ou rap.

Nos intervalos, há intensa circulação pelas banquinhas que vendem comida vegana a preços baixos, assim como a troca e venda de fanzines e outros materiais iconográficos, os quais são objeto de atenção neste artigo. A divulgação dos eventos acontece principalmente por listas de e-mails e redes sociais - utilizando não só o site Facebook, mas também outras plataformas consideradas mais seguras e em consonância com a almejada autonomia. O público pode variar de 30 até 300 pessoas, a depender do evento e do tipo de atividade.

Essas atividades são informais e organizadas por coletivos - um termo nativo recorrente. O coletivo é categoria fundamental e organizativa desse campo jovem. Em meio às ativistas da rede pesquisada, é termo que diz respeito aos agrupamentos cujas integrantes mantêm relações de afinidade e amizade entre si; são arranjos instáveis e contingentes, de número cambiável de integrantes. Há, portanto, uma "política do afeto" sobre a qual os coletivos se apoiam e que de certo modo explica a vida curta de muitos coletivos e a efemeridade dessas agrupações, que se fazem e refazem conforme as relações de afeto são remodeladas dentro de um campo bastante conflitivo.

Os eventos, frequentados sobretudo por jovens que em geral se identificam como mulheres, lésbicas e/ou trans, além de representar momento de discussão política sobre temas em um amplo leque, como autonomia e horizontalidade, tecnologia e mídia livre, anarquismo, pornografia feminista, alimentação, etc., são também espaços de sociabilidade, em que há o flerte, a paquera e a formação de novos contatos e amizades. É, por conseguinte, um quadro que torna bastante difícil, senão impossível, traçar uma linha divisória entre, de um lado, ativismo e política, e, de outro, diversão e sociabilidade. As duas dimensões são igualmente constituintes dessa rede ativista e estão mutuamente imbricadas na construção desses sujeitos.

As atividades etnografadas se mostraram lócus primordial para aquisição de produções como fanzines, panfletos, livros, cartazes e livretos que circulam nessa rede. Neste artigo, a análise de documento será utilizada para a investigação dos fanzines - elemento que se mantém fortemente no campo, apesar da disponibilidade e do uso recorrente das tecnologias de comunicação mediadas por computadores -, assim como de cartazes e outras produções iconográficas e textuais.

Zines são publicações em papel, geralmente compostas por colagens feitas à mão, de modo que textos ou desenhos são impressos, recortados e colados em folhas de papel que então são montadas em determinada ordem e xerocadas. Esse tipo de elaboração manual é uma característica-chave dos zines ou fanzines. o baixo custo e a facilidade de confeccionar um zine fizeram com que ele se tornasse um dos principais meios de expressão das ideias e da música punk 
(Magalhães, I993 apud Camargo, 20I I) - uma referência musical, política e estética constante nesse circuito. ${ }^{5}$

É de valia, contudo, chamar atenção para a linguagem marcadamente universitária, notável na presença da língua inglesa e no repertório de termos, como no próprio padrão de caligrafia dos fanzines expostos - o que termina pondo em perspectiva a não exigência da técnica e da especialização de funções, reatualizando padrões excludentes no interior de uma rede ativista bastante hermética.

Tendo como ponto de partida questões relativas a corporalidade e estilos na produção de sujeitos, este texto indaga como processos de hifenização são encarnados e tomam forma no ativismo - entendido em termos de discursos e práticas cujo efeito de materialização possui caráter performativo (Butler, 2010). Destarte, interessa investigar, no campo etnográfico, o que conta como corpo, onde ele começa e termina, quais são as suas funções, quais são os regimes de (im)permeabilidade de fluidos e trocas corporais que gerem limites e fronteiras particulares implicadas na reinvenção de convenções de gênero e sexualidade.

Partindo da crítica de autoras como Judith Butler (2003) e Donna Haraway (2009) às identidades coerentes e corpos estáveis, e da assertiva de FaustoSterling (200I) de que incorporamos a experiência a nossa carne, o intento, portanto, consiste em desenvolver análise documental etnográfica para entender a maneira particular com que o corpo se apresenta na iconografia. Tais produções - fanzines, livros, cartazes de eventos - condensam e materializam o múltiplo pertencimento político dessas ativistas, expondo igualmente seus trânsitos contenciosos por outros movimentos sociais, assim como pela academia. Mais do que expressar ou manifestar uma dada identidade preexistente, os corpos que ocupam as ruas ou as páginas dos zines "constroem as diferenças sobre as quais e em nome das quais falam" (Coelho \& Victora, 20I7: I62).

As produções gráficas que encontramos nesse material de campo mostram corporalidades híbridas, que exploram as fronteiras não só de gênero, como de sexualidade e de espécie, pois se utilizam de referenciais animais para construir sua representação. Sugiro, por fim, que elas corporificam e encarnam esse pertencimento múltiplo do qual venho falando, e iluminam a interpretação ativista acerca do debate das chamadas interseccionalidades.

Sendo intimamente envolvida com o universo da pesquisa, essa liminaridade entre as posições de pesquisadora e ativista se mostra também condição sine qua non para a própria exequibilidade da pesquisa, considerando o caráter hermético da rede ativista. Tal ambiguidade, que já foi vivenciada por outras/ os pesquisadoras/es em movimentos sociais, como Regina Facchini (2005), Maria Filomena Gregori (I993) e Edward MacRae (I990), por exemplo, tem sido acompanhada pelo esforço do estranhamento analítico e por precauções de cunho ético, especialmente com relação à publicação de dados provindos do trabalho de campo. 


\section{ESPÉCIE, GÊNERO E SEXUALIDADE EM QUESTÃO}

O Sapatoons Queerdrinhos (SQ) ${ }^{6}$ é um fanzine recheado de desenhos e histórias em quadrinhos, que existe desde 20I 2, contando hoje com três edições. Em um evento realizado em 2015 na cidade de São Paulo, o SQ foi descrito como um projeto colaborativo, que circula em listas de e-mail anarquistas, composto por histórias fictícias e biográficas sobre amigas e voltado para essa própria rede, vista como uma comunidade afetivo-política habitada por um "nós, as lésbicas, as trans". Por meio dele seria possível registrar histórias e piadas a respeito de experiências pessoais tornadas coletivas, que, compartilhadas, têm a capacidade de forjar laços entre quem lê, construindo assim vínculos, amizades, comunidades de pessoas que se conectam e passam a fazer sentido juntas. ${ }^{7}$

A produção de neologismos e de novas grafias é parte da estratégia de expressão dos fanzines e está implicada no alargamento do léxico feminista. A palavra "Sapatoons" faz alusão ao termo acusatório, aqui empregado como categoria de autonomeação, "sapatão" e a "cartoons" (do inglês, desenho animado). Já "queerdrinhos" remete a "queer" (categoria acusatória na língua inglesa) e "quadrinhos" (uma referência ao conteúdo do zine, que é composto por tirinhas). A criatividade dos neologismos se relaciona também com o uso do humor - especialmente no formato do deboche e da chacota - o que evidencia uma relação crítica com a respeitabilidade e o âmbito do que se entende como institucional.

Numa perspectiva autolocalizada como "trans, sapatão, queer", os quadrinhos narram experiências na família, no círculo de ativismo, em relações afetivas e situações cotidianas, vivenciadas por personagens que se veem frente a relações de poder reguladas por normas acerca do que seria uma conduta "natural" ou "normal" em sua sexualidade ou apresentação de gênero.

Após I5 histórias ilustradas nos quadrinhos e ocorridas no interior de cenários diversos - como banheiros públicos, festas, ônibus, quartos, entre outros -, encontramos o desfecho do Sapatoons Queerdrinhos numa cozinha. O "episódio" intitula-se "uma historinha feliz", e a personagem principal, vestindo avental estampado com patos, no qual podemos ler a palavra "vegan", anuncia: "Olá, esse quadrinho é dedicado a todxs que acham que não passo de uma lésbica amargurada, sem amigues, que só faz desenhos derrotistas! Então, anotem aí, sapas!". 


\section{UMA HISTORINHA FELIZ}

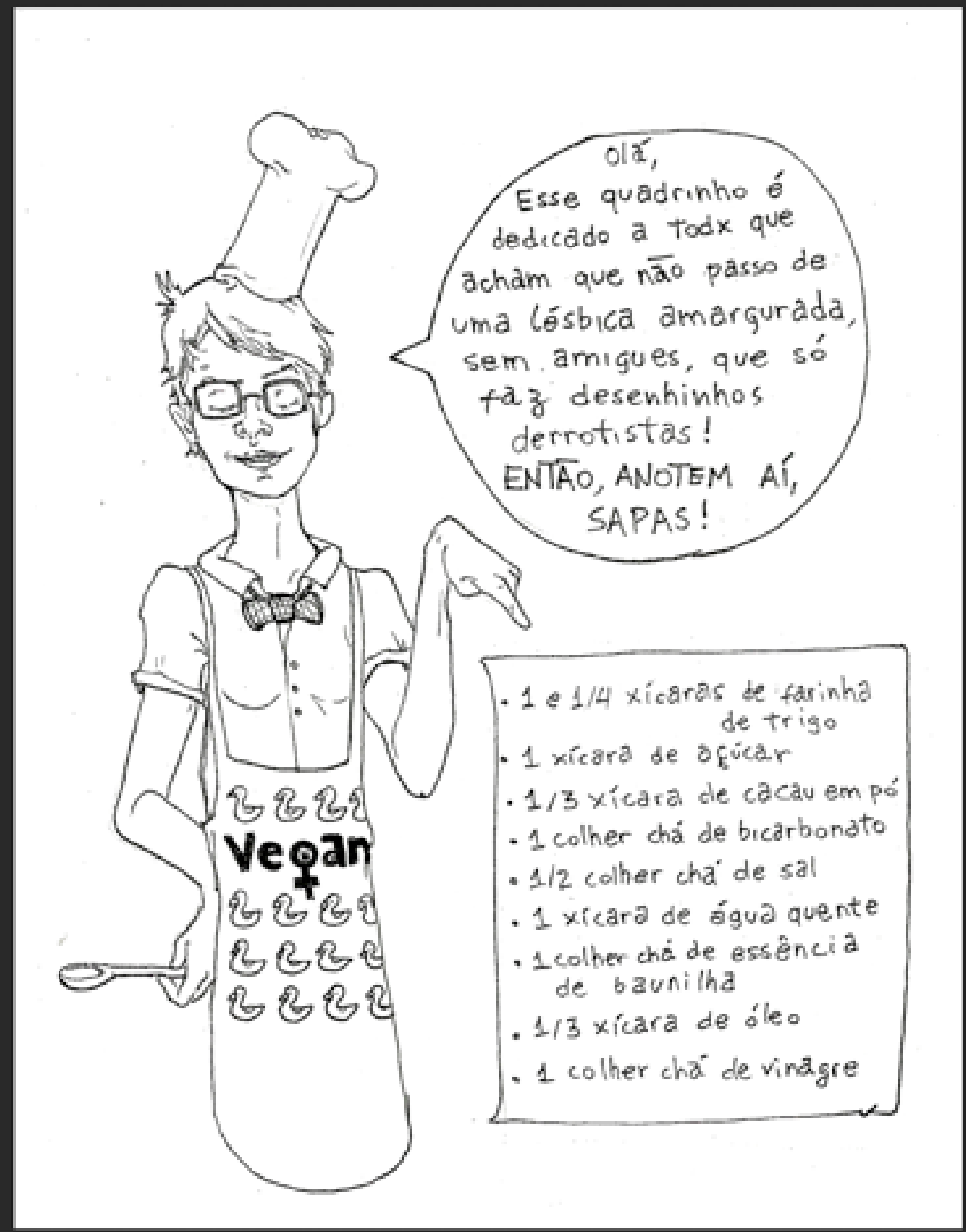




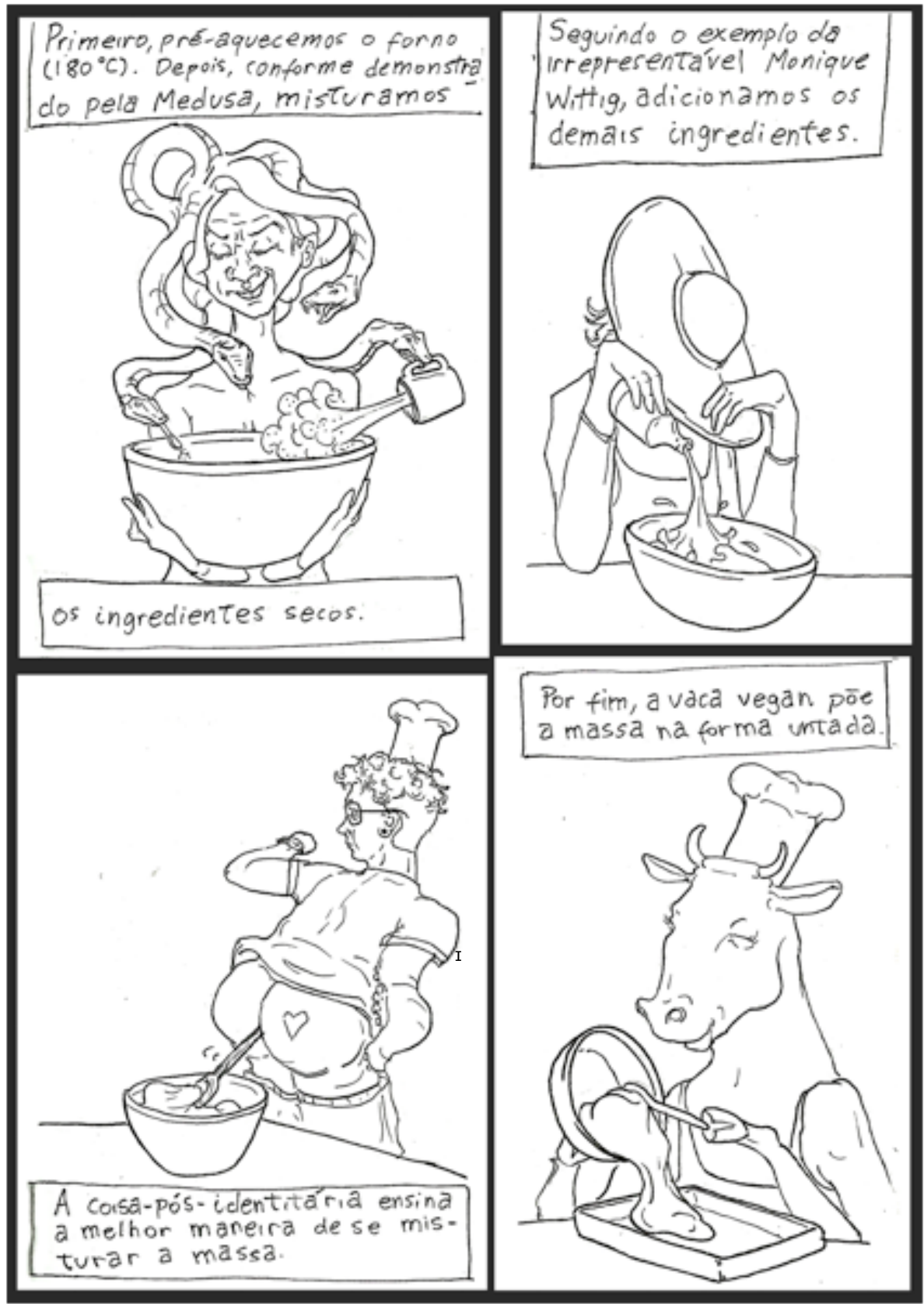




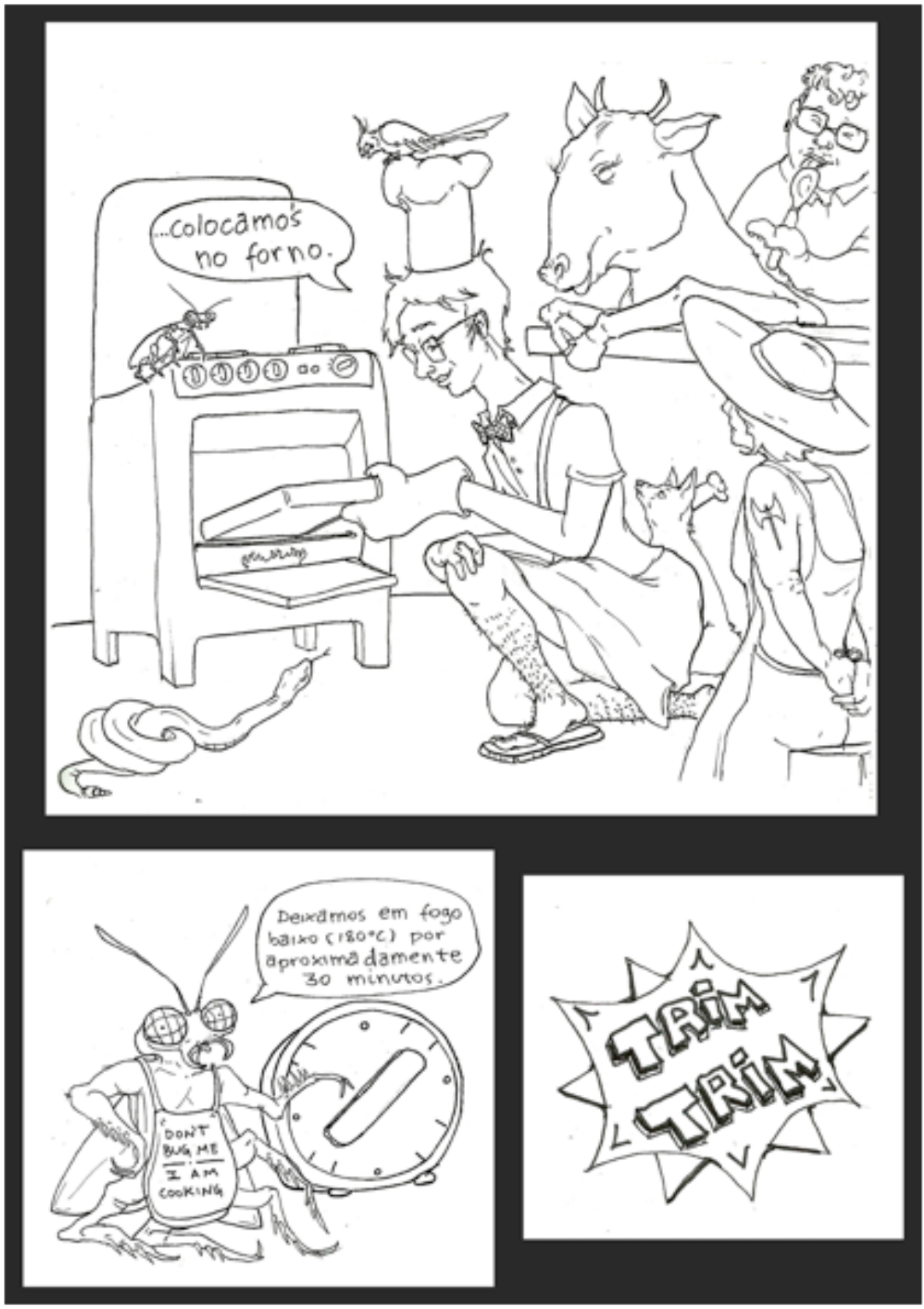


O termo "amigues" é usado como forma de fugir do universal masculino ("amigos"), mas também reflete um feminismo que não tem a "mulher" como seu sujeito estável e a priori - sendo recorrente a utilização, na linguagem escrita (muito comum nos zines), das letras "i" ou "x" ou ainda “@” no lugar das vogais que demarcam o gênero gramatical, denotando certa instabilidade nas posições de sujeito -, mas que tem, contudo, o homem cisgênero como seu exterior constitutivo. ${ }^{8}$

Subsequentemente há uma explicação de como fazer um bolo vegano de chocolate, cujas instruções são informadas e protagonizadas com a ajuda de uma medusa, uma personagem identificada como a autora feminista francesa Monique Wittig com um labrys ${ }^{9}$ estampado no braço, uma vaca, um pássaro, um gato e um besouro.

Como lembra Juliana Abonizio (20I6: I I9), "há vários tipos de consumo que compõem o vegetarianismo, e as motivações que levaram à adoção e levam à manutenção da dieta (que podem ser variáveis, sucedâneas ou concomitantes) implicam diferentes atitudes em relação à carne", bem como diferente atribuição de sentido. Dito isso, o significado de dizer-se vegetariano/a não pode ser tomado aprioristicamente uma vez que há vários vegetarianismos.

Em termos descritivos, a pessoa vegana é definida como aquele sujeito que se abstém não apenas da ingestão da carne de animais (em geral define-se assim o vegetariano), mas de quaisquer produtos oriundos de seus corpos, como leite, ovos e mel. Também é evitado o consumo de produtos em que tenha sido pressuposta a exploração desses corpos de outros modos, como o caso de cosméticos testados em animais, produtos de limpeza doméstica, corantes presentes em biscoitos e outros aditivos químicos em alimentos industrializados. O veganismo frequentemente também abarca outros aspectos: no vestuário, há a interdição do couro e da lã; no entretenimento, o boicote a zoológicos, touradas, e circos com animais, e, por fim, há ainda o engajamento na luta pelo fim da vivisseção (Carmo, 20I3).

O "final feliz" do quadrinho (ver página seguinte) é materializado por um imponente bolo confeitado e desenhado em primeiro plano, vendo-se ao fundo as silhuetas de quem o fabricou, e sobre o qual se lê, escrito em confetes, "feliz ruína da heteronorma" - uma referência à normatização da heterossexualidade enquanto condição supostamente natural assentada no binarismo de gênero.

A filósofa Carol Adams (2012) argumenta que, para que a carne exista, animais - antes possuidores de um nome e um corpo - se tornam "referentes ausentes" e, numa operação simbólica, são transformados em comida. Assim, em nossa linguagem, o uso de "carne" não evoca morte ou animais retalhados, contribuindo para a ausência dos animais: vacas, depois de mortas, são fragmentadas, se tornam bifes, rosbifes, hambúrgueres - referenciais, para Adams, menos inquietantes. O referente ausente permite que esqueçamos o animal como uma entidade independente. 


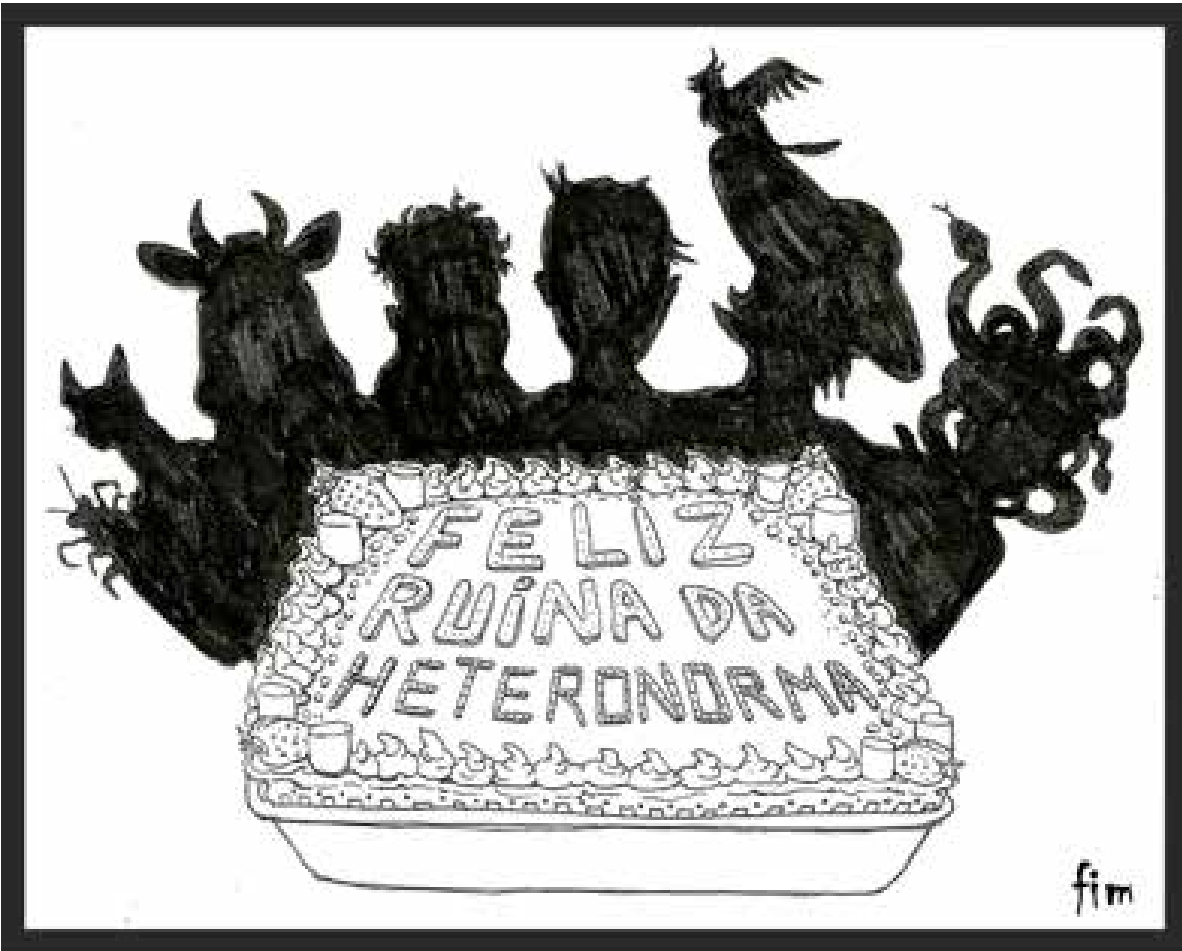

Id

Sapatoons Queerdrinhos (20I2)

Fonte: Arquivo pessoal.

É possível então dizer que a "historinha feliz" - e talvez sua qualidade assumidamente "feliz" seja devedora dessa operação - restaura o referente animal ausente ao imputar uma agência àqueles animais cujos corpos são pensados em algum tipo de relação de consubstancialidade e interdependência com os corpos humanos que protagonizam as histórias do SQ.

A disposição desses agentes no quadrinho sugere, assim, algum tipo de qualidade compartilhada entre esses corpos, o que desemboca na discussão sobre fronteiras e (im)permeabilidades a ser realizada nas próximas seções.

\section{TECNOLOGIAS DE GÊNERO}

Ocorrido na cidade de Salvador (BA) entre 20I I e 20I3, o Festival Vulva la Vida (FVLV) foi o evento no qual iniciei minha pesquisa de campo ainda no mestrado, e de cuja organização eu também fazia parte. Foi o principal meio pelo qual pude estabelecer contatos que me levariam aos demais eventos que posteriormente conformaram o universo empírico da pesquisa. Ademais, o FVLV é men- 
cionado em diversos trabalhos recentes sobre "feminismos jovens" (Carmo, 2013, 20I6a, 20I6b; Alvarez, 20I4a; Gonçalves, Freitas \& Oliveira, 20I3; Ribeiro, Costa \& Santiago, 2012).

Oliveira e Gonçalves (2016: 248), por exemplo, consideram o evento "local privilegiado de confluência" de jovens que não se vinculam a nenhuma organização formal, atuando principalmente em coletivos e grupos diversos - às vezes simultaneamente, como pontuam (p.248). Outras autoras, como Alvarez (20I4a: 37), citam o festival para tematizar a emergência de novos campos discursivos no feminismo brasileiro e latino-americano. Ela conta que realizou entrevista com fundadoras e participantes, dentro de um grupo de "outras jovens militantes de várias identificações raciais e setores políticos como o veganismo, transfeminismos, hip hop, reggae e capoeira".

Como nos demais eventos, no FVLV não havia divisão de trabalho especializada, isto é, não havia distinção preestabelecida entre quem organizava, quem agendava show, quem limpava o espaço, quem promovia debates. As funções eram colaborativas e livremente assumidas.

Assim, por exemplo, o cartaz da divulgação não foi feito por um profissional do design ou das artes. A mesma lógica opera nos fanzines, bandas, coletivos: ao menos a princípio, qualquer uma pode se engajar nessas atividades, as quais não requerem técnica profissional, determinado "talento" ou diploma. Essa fluidez igualmente permite que os eventos, assim como zines, sejam espaços e artefatos de experimentação sexual e de gênero - em que arranjos são testados, novas linguagens são forjadas e formas de marcar (e produzir) diferenças são ensejadas. Esse argumento, contudo, só faz sentido se considerados os pertencimentos de classe, escolaridade e raça das interlocutoras, assim como a sua localização em espaços urbanos. ${ }^{\text {io }}$

Nos dados do trabalho de campo realizado desde 2012 em eventos - entre eles a terceira edição do FVLV - observei que a comida vegana e os rituais de comensalidade ocupam lugar notório, que foge à posição de suporte ou acessório. Trata-se de "atividades" e não apenas forma de alimentar as pessoas para que se mantenham presentes. Nos eventos dessa rede ativista, a comensalidade é entendida como parte da práxis e enquanto tal é constituinte da programação dos eventos, tendo tanto peso ou, na prática, quase tanto peso quanto as demais atividades. Como argumentei outrora, os códigos alimentares e as prescrições que regem a "performance culinária" (Tobin, I999) vegana feminista ressignificam a cozinha, construindo-a como espaço de agenciamento interespécie e de contestação das convenções de gênero dominantes (Carmo, 2013; Carmo, 20ı6a). ${ }^{\text {II }}$ Dito isso, faz sentido a presença da receita de bolo figurando nas páginas do fanzine exposto.

Um dos cartazes de divulgação da segunda edição do FVLV realizado em Salvador (BA) expressa uma cosmologia política povoada por referências ao não humano, as quais, articuladas em "acoplamentos ciborguianos" (Haraway, 2009), 
jogam com os limites da representação coerente. Como será discutido na próxima seção, podemos entrever no cartaz a busca da politização de orifícios corporais e a reinscrição de regimes de (im)permeabilidade.

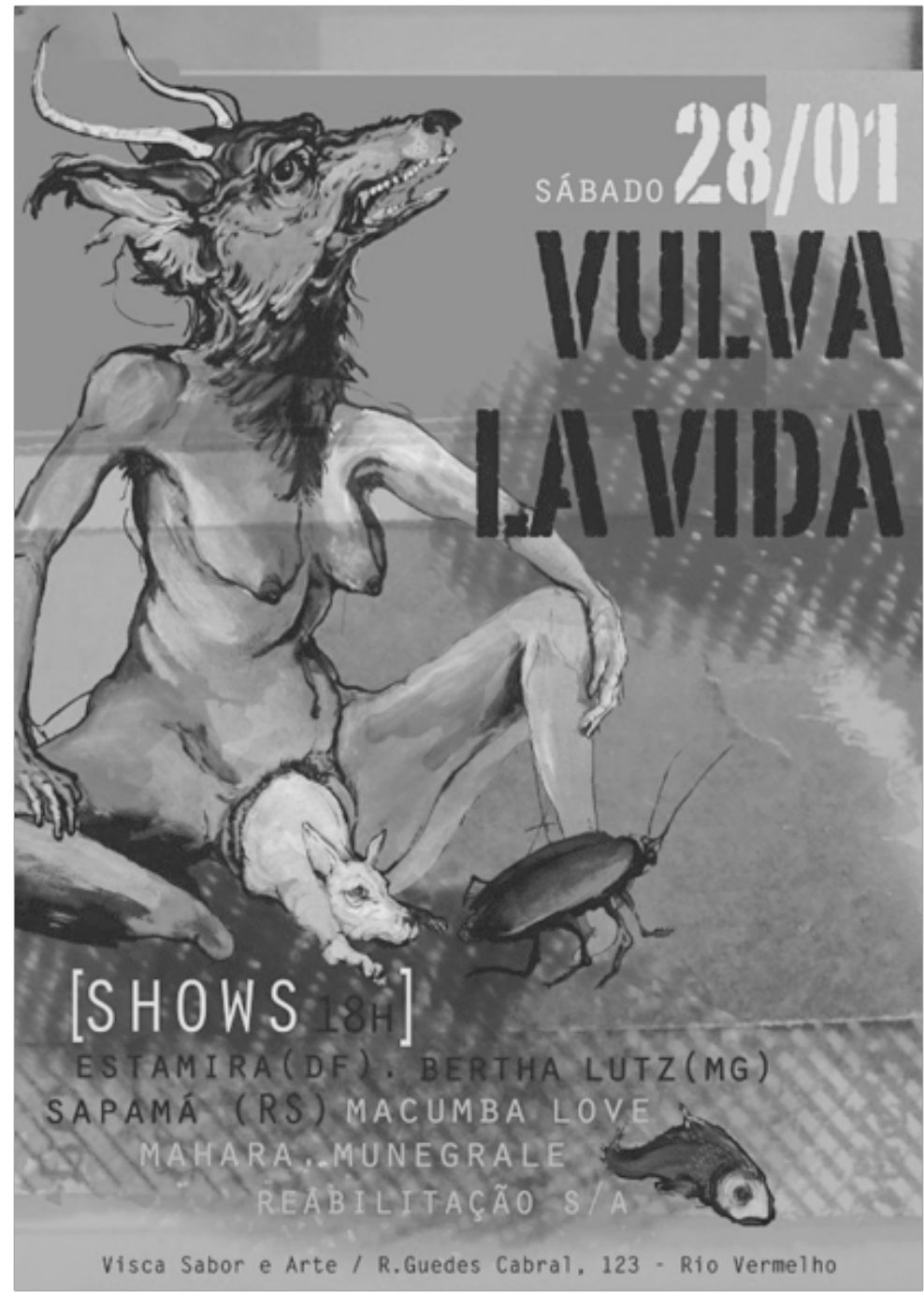

2

Cartaz de divulgação do FVLV (2012)

Fonte: Arquivo pessoal. 
No campo etnográfico, a interdição vegana está profundamente articulada com uma crítica ao chamado especismo, termo que denota uma relação de opressão e exploração aos animais enquanto espécie. Sustento que, nesse circuito ativista, a eficácia do termo especismo está atrelada a uma profusão discursiva de muitas categorias e neologismos criados nesse contexto, em uma cadeia de significados, como gordofobia, lesbo-homo-transfobia, etarismo e adultismo, capacitismo, etc. Há intensa relação de circulação e retroalimentação com o âmbito acadêmico, cujas categorias são reapropriadas, contestadas, tensionadas em seus sentidos, a partir das estratégias ativistas (Carmo, 2016b).

Teresa de Lauretis (I994: 208), preocupada em traçar um conceito de gênero que não fosse considerado uma derivação da diferença sexual nem um mero efeito ideológico da linguagem, propôs a categoria "tecnologia de gênero", segundo a qual gênero não diz respeito a uma propriedade de corpos, mas, parafraseando Foucault, "ao conjunto de efeitos produzidos em corpos, comportamentos e relações sociais, por meio do desdobramento de 'uma complexa tecnologia política'”.

O cinema é um exemplo de tecnologia de gênero sobre o qual a autora se debruça. Aqui será sugerido que o manejo, significado e sentido atribuídos à comida vegana fazem dela uma tecnologia de gênero dentro de uma gastropolítica particular, a partir da qual podemos compreender o investimento político nos estilos corporais, na gordura e na hibridez interespécie.

Nesse sentido, o veganismo, tal como manejado e performativizado por essa rede, constitui uma tecnologia política cujo efeito discursivo recai na produção de corpos que reivindicam espaços intersticiais. Ele faz parte de um universo de críticas a concepções que relacionam o corpo a uma "condição normal" - como o corpo supostamente acima do peso.

\section{SOBRE DOBRAS, DOBRADURAS E DOBRADIÇAS: REGIMES DE (IM)PERMEABILIDADE}

Inspirada nos trabalhos de Mary Douglas e Julia Kristeva, Judith Butler (2003) sugere que a fronteira e a superfície dos corpos são politicamente construídas mediante os tabus da matriz heterossexual. Para desenvolver tal argumento, a autora faz uma leitura da obra Pureza e perigo, propondo uma apropriação pós-estruturalista de suas ideias a fim de compreender o corpo em sua discursividade. Butler (2003: I88) defende que discursos estabelecem as fronteiras da pele, instaurando e naturalizando "certos tabus concernentes aos limites, posturas e formas de troca apropriadas, que definem o que constitui o corpo". Aqui, proponho que o veganismo é uma dessas modalidades de trocas, ao lado de discursos sobre (homo)sexualidades, redefinindo o que conta como o corpo saudável, desejável, bem como o que conta como corpo comestível, edível.

Se, como coloca Douglas, a poluição de fronteiras - a junção daquilo que deve estar separado e a ruptura simbólica daquilo que deveria estar junto - re- 
presenta perigo em uma variedade de culturas, para Butler (2003: I90) também a permeabilidade corporal é regulada de forma normativa:

As práticas sexuais que abrem ou fecham superfícies ou orifícios à significação erótica em ambos os contextos, homossexual e heterossexual, reinscrevem efetivamente as fronteiras do corpo em conformidade com novas linhas culturais. [...] Além disso, os ritos de passagem que governam os vários orifícios corporais pressupõem uma construção heterossexual da troca das posições e das possibilidades eróticas marcadas pelo gênero. A desregulação dessas trocas rompe, consequentemente, as próprias fronteiras que determinam o que deve ser um corpo.

Dito isso, interessa-me nesta seção alargar a reflexão proposta pelas autoras, de modo a pensar os processos de subjetivação que têm sua centralidade no corpo - um corpo cujas trocas e permeabilidades forjam dobras e dobradiças em contestação à violência dos estigmas e representações dominantes sobre gênero, sexualidade e gordura.

A décima edição do Seminário Internacional Fazendo Gênero ocorreu na cidade de Florianópolis (SC) em 2013 e tinha como um de seus objetivos "criar espaços de troca de experiências e diálogo entre investigadoras/es acadêmicas/ os e aquelas/es ligadas/os a outras entidades e aos movimentos sociais". ${ }^{12} \mathrm{Ne}-$ la encontrei algumas das interlocutoras dessa pesquisa, mais especificamente na atividade "Exposição Internacional Arte e Gênero", em que aconteceu uma oficina sobre "violência entre lésbicas", uma performance de lançamento de fanzine e shows com bandas feministas de funk e de música eletrônica no qual, à diferença do restante do seminário, a única comida à venda era expressamente vegana, sendo organizado em parceria com o coletivo Vadias Desterro, também responsável pela versão local da Marcha das Vadias. ${ }^{13}$ Assim como acontece com o termo "vadia", algumas das bandas que se apresentaram - chamadas Sapatânicas e Putinhas Aborteiras - se apropriam e positivam categorias de acusação, como "sapatão" (Diário de campo, Ig set. 20I3).

O fanzine lançado na ocasião tem por título "Gorda, Eu?!?" e como subtítulo "Um zine sobre dobras, dobraduras y dobradiças". É um zine pequeno, menor do que os usuais, que cabe na palma da mão. O conteúdo alterna autorretratos e frases escritas à mão por um "eu, gorda". Ambos os recursos imprimem no papel o lugar de fala reivindicado pela autora, que se identifica como "uma lésbica gorda negra".

Penso que a linguagem da letra cursiva, a expressão de experiências pessoais, o autorretrato e a exposição do corpo remetem ao que Hall (2000: I09) chama de "narrativização do eu", a qual envolve o manejo e negociação "da utilização dos recursos da história, da linguagem e da cultura para a produção não daquilo que nós somos, mas daquilo no qual nos tornamos". Assim, é um processo contingente que tem a ver

não tanto com as questões 'quem nós somos' ou 'de onde nós viemos', mas muito mais com as questões 'quem nós podemos nos tornar', 'como nós temos sido 
representados' e 'como essa representação afeta a forma como nós podemos representar a nós próprios' (Hall, 2000: I09).

Nesse processo de formação discursiva do sujeito, o corpo não funciona como um referente estável, mas como uma espécie de significante que condensa as subjetividades nos indivíduos, os quais são não só convocados a determinadas "posições de sujeito", mas também moldam, estilizam, produzem, tensionam e exercem essas posições (Hall, 2000).

Conforme o trecho na imagem 6 (página seguinte), no zine é criada uma cadeia de significados que permeia a sexualidade, a gordura e a identidade racial, dando lugar a uma lesbianidade que se erige em oposição à feminilidade supostamente inerente à "mulher". Outro trecho, subsequente, afirma: "nesses dias fiquei menos gorda, o assédio aumentou; ainda acho estranho, "por que eles me veem como mulher?'. muitas vezes experimento minha gordura como alguma estratégia que me leva longe do que é 'feminino', 'ser mulher'”.

A "indisponibilidade pra homens" é sinalizada, entre outros aspectos (como a raça), mediante a gordura - "nesses dias fiquei menos gorda, o assédio [masculino] aumentou". A gordura mobiliza e condensa um lugar de contestação à inteligibilidade de gênero, encarnando uma identidade para longe do "feminino" e em direção à assunção das bordas, dobras e dobradiças, como evocado no título. As dobras representam um jogo deliberado com os códigos de regulação dos contornos corporais, manejando signos que visam à ampliação das possibilidades corporais.

No zine em questão, a estabilidade da distinção interno/externo é contestada também mediante alimentação, levando a um agenciamento interespécie. A página abaixo comunica "pra mim, ser vegana (antes vegetariana) tem tudo a ver com ser gorda, porque não é uma dieta sobre emagrecer, mas sim sobre outras pessoas (principalmente as não-humanas), o foco não é só eu mesma, (m)eu corpo...".

Esse corpo é favorecido mediante o veganismo, e, pelo fato de ele não ser uma matéria inerte, mas, antes, um lugar político de enunciação de um "eu, gorda", o veganismo diz respeito a mais do que "corpos", diz respeito a pessoas, ao estatuto do humano e do animal. Se muitas vezes os vegetarianismos são evocados para instrumentalizar o corpo magro pela perda de peso, em direção ao que seria um padrão excludente e a serviço da matriz heterossexual, aqui, o veganismo concerne ao corpo que escapa aos ideais regulatórios de gênero, sexualidade e espécie. Parece que a busca de reinscrever as fronteiras do corpo em novas linhas culturais, como coloca Butler, se vale da comida como tecnologia de subjetivação humana e animal. 


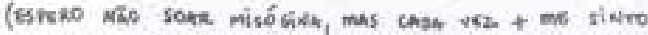

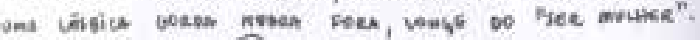

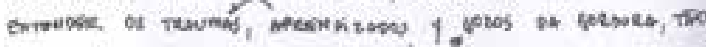

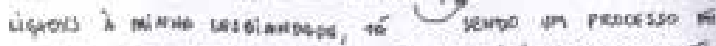

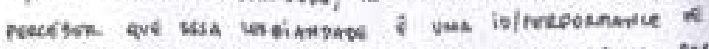

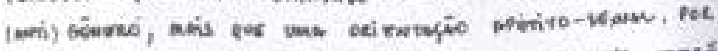

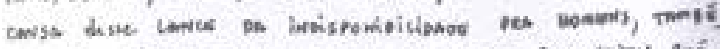

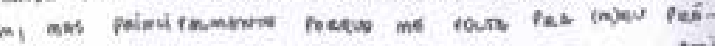

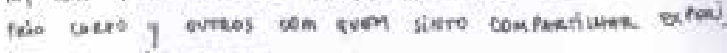
kavus, pevetos, wras...

i. uses ne sinto wite
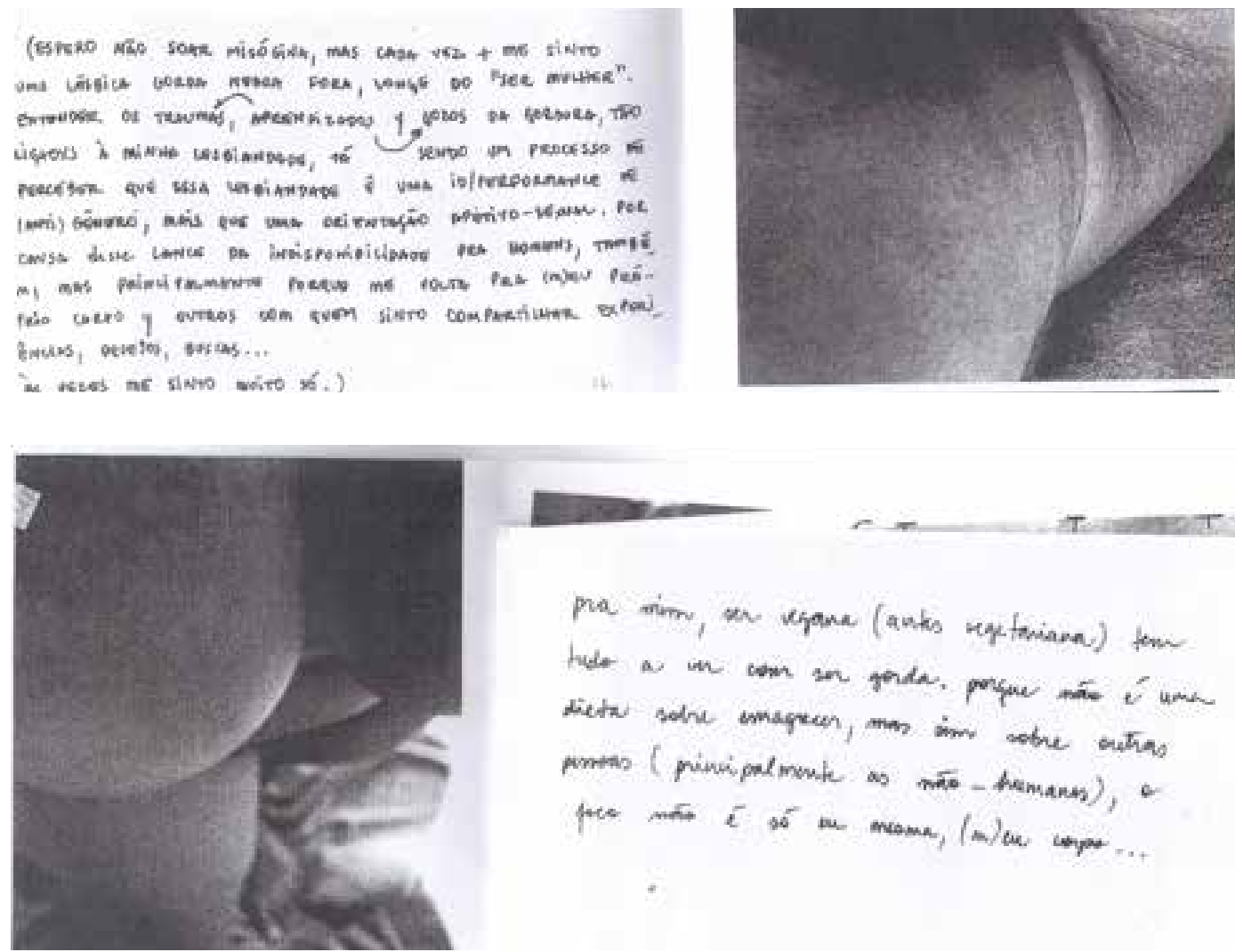

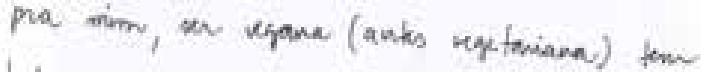
hele a in com un gada. porgue nât í uma

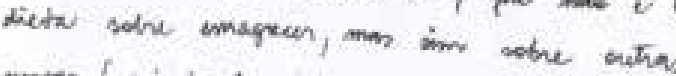
puntas (pinipalmente as nato-hemans), c

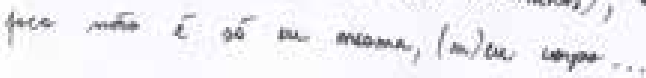

Páginas do zine Gorda, Eu?! (2012)

Fonte: Arquivo pessoal.

4

Páginas do zine Gorda, Eu?! (2012)

Fonte: Arquivo pessoal. 
A "performance de (anti)gênero" I4 tal como expressa no zine aponta para a centralidade que o corpo possui para os feminismos contemporâneos e seus ativismos estilizados, com a ressignificação ou aprofundamento do lema "o pessoal é político". Nesse contexto, a estratégia feminista de "politização do privado" permanece, portanto, como referencial, mas pode ter como alvo novas áreas da vida ou, ao menos, sua politização pode se dar de forma qualitativamente distinta. Aqui, o corpo é, em si e desde já, bandeira política (Carmo, 20ı6b).

É de valia notar que, dado o ângulo bastante aproximado, nas imagens do zine não é possível ver o tamanho do corpo, mas sim sua textura, contorno e dobras sobrepostas. Aqui há um diálogo a ser feito com trabalhos sobre corpos gordos, como o livro Unbearable weight, de Susan Bordo (I993). Segundo a autora, até os anos I980, o excesso de peso era o alvo da maioria dos anúncios de produtos de dieta; a partir de então, o alvo passa a ser representado por termos como gordura, saliência, flacidez - que não estão estritamente associados ao excesso de peso. A ênfase não se volta tanto para a perda de peso, mas sim tem a ver com a busca de margens corporais firmes - daí a popularização de técnicas como a lipoaspiração e de combate à celulite, por exemplo. O corpo firme e contido comunica mensagens de autocuidado, energia, controle sobre impulsos e habilidade em moldar a própria vida. Esses são sentidos mediados por qualidades morais, uma vez que a gordura é percebida como indicativo de preguiça, falta de disciplina, etc.

Tendo como uma de suas inspirações o fanzine supracitado "Gorda, Eu", o livro La cerda punk: ensayos desde un feminismo gordo, lésbiko, antikapitalista y antiespecista ("A porca punk: ensaios desde um feminismo gordo, lésbiko, anticapitalista e antiespecista"), de autoria de Constanza Alvarez Castillo, foi lançado no Chile em 20I4. ${ }^{15}$ Desde então ele tem circulado no Brasil em meio digital, assim como recentemente têm acontecido lançamentos itinerantes pelo país em cidades como Brasília (DF), Belo Horizonte (MG), São Paulo (SP) e Rio de Janeiro (RJ), contando com a presença da autora. Também tem sido veiculada uma tradução do livro para o português no formato de fanzine.

Estive presente no evento de lançamento na cidade do Rio de Janeiro, que contou com cerca de 40 pessoas e aconteceu em um local no Centro da cidade, o Motim, que se define como "um espaço livre para shows, atividades artísticas, insubmissas, rebeldes e independentes". ${ }^{16} \mathrm{~A}$ atividade contou com uma roda de conversa com a autora, além de exibição de vídeo pós-pornô, performance e show de banda punk.

O livro, que tem 243 páginas, está em sua terceira edição e foi então vendido pelo valor de $\mathrm{R} \$ 35,00$. Além dele, a autora, de 24 anos, também vendia fatias de bolo vegano de cenoura com chocolate e amendoim a fim de custear sua própria viagem.

A apresentação foi feita em "portunhol", para uma roda de pessoas sentadas em círculo no chão do Motim. Castillo contou que vive na cidade de 


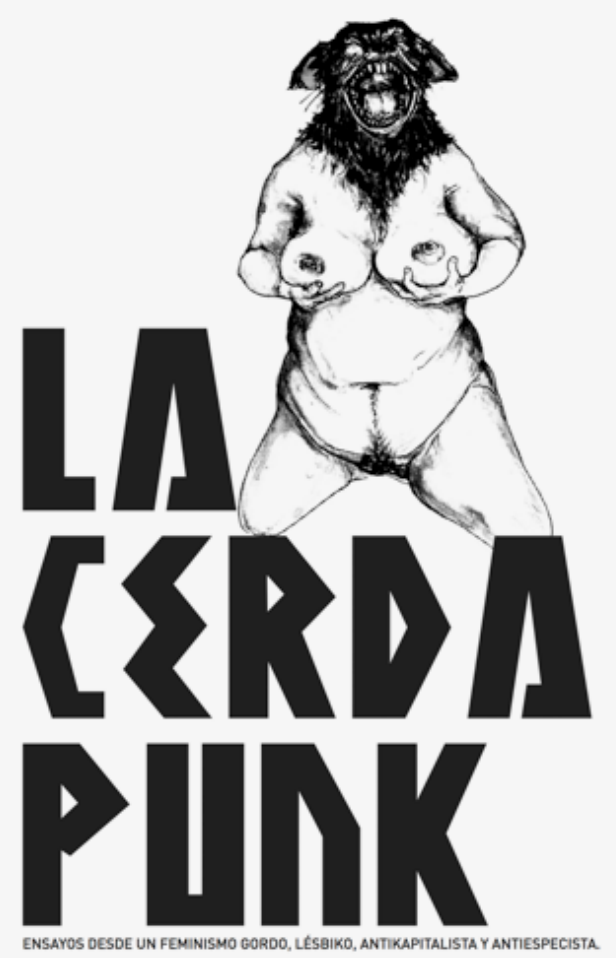

5

Capa do livro La cerda punk (2014)

Valparaíso, no Chile, onde o livro foi escrito enquanto vivia de forma precária em uma okupa. ${ }^{\mathrm{I} 7} \mathrm{La}$ cerda punk teve seu primeiro lançamento na Feira do Livro Anarquista de Valparaíso em 20I4, e foi descrito como um projeto autogestionário, uma vez que funções como edição, diagramação, publicação e reprodução foram feitas de forma colaborativa por amigos e pessoas que nele acreditavam. Assim, ele seria um exemplo de que qualquer pessoa pode escrever um livro, produzindo conhecimento fora da universidade (Diário de campo, 2 I jan. 20 I7).

$\mathrm{Na}$ capa, uma ilustração assinada por Lino Arruda: um corpo de coxas grossas, virilha peluda, barriga protuberante, mãos que seguram seios fartos e uma cabeça furiosa, meio-lobo, meio-cachorro. ${ }^{18}$

O prólogo, assinado pela ativista Valeria Flores (20I4: I I), elenca uma série de qualificações multissituadas para localizar a autora: "aquí no se habla de cualquier cuerpo, es un cuerpo gordo, lesbiano, anarquista, feminista, antiespecista, practicante de BDSM, sudaca, posporno, glam trash". Há um jogo de palavras com o termo straight, que na língua inglesa possui ao menos dois sentidos: I) é um 
adjetivo sinônimo de "reto", sem curvas; 2) é utilizado também com o sentido de "heterossexual". O trocadilho permite que Flores defenda a assunção desse corpo gordo como aquele que não aspira a ser straight, mas que, antes, se assenta em "curvas hiberbólicas" e "zigzagueantes".

O referencial animal é mobilizado a fim de politizar a gordura. Após o prólogo, a autora começa o livro enunciando "escribo desde la cerda punk que me habita y su gruñido es um grito de guerra" (Castillo, 20I4: 25). Adiante ela relata que cerda (porca), vaca (vaca), ballena (baleia), foram os insultos que desde muito pequena passaram a fazer parte de seu imaginário.

A escrita autobiográfica, que mais uma vez remete à "narrativização" do eu, se impõe a fim de enfrentar a pressuposição de que os hábitos alimentares de mulheres gordas não são válidos, pois se alimentariam compulsivamente sem consciência do que põem na boca. Vista como um órgão exposto e vigiado socialmente de modo intenso, a boca é alvo de investimento político a partir do veganismo, em uma sociedade em que vegetarianismo e gordura são tidos como oximoros. Tendo que conviver com comentários como "por que és gorda se és vegana?" - os quais subentendem que qualquer tomada de ação por uma pessoa gorda visa ao emagrecimento, e que pessoas veganas só comem saladas -, Constanza Castillo questiona a suposta irracionalidade que guiaria a relação das mulheres gordas com a alimentação.

Em oposição deliberada ao "orgulho gordo" e ao plus size, o livro traz a proposta de ver a gordura não sob o prisma da vitimização, mas através de um olhar feminista lésbico voltado para "cómo las distintas mujeres utilizan distintas estratégias con su propio cuerpo para alerjase de la heterosexualidad y del deseo del varón" (Castillo, 20I4: 77-78), isto é, "ser gorda para no ser un objeto de deseo del varón". Assim, o corpo lésbico gordo seria aquele que (r)existe mediante a desprogramação do desejo heterossexual, estratégia traduzida como "sabotaje sexual" e "hackeo del cuerpo".

Embora com base em uma interpretação dualista em termos de poder/ corpo, Bordo (I 993) fornece um contraponto interessante sobre essa questão. Ao se debruçar sobre a chamada anorexia nervosa, no contexto da década de I 980 nos Estados Unidos, a autora argumenta que, tal qual expresso nos relatos de adolescentes anoréxicas, a magreza é vivenciada em oposição ao "corpo feminino", entendido como um corpo arredondado (a round body), e associado ao papel tradicional voltado para a vida doméstica. Essa imagem era responsável por moldar a experiência dessas jovens frente a sua própria fome de comida. Tal "temor" pela feminilidade (a fear of womanhood) desenvolvido na puberdade carrega, segundo a autora, uma dimensão de protesto contra as expectativas de gênero vigentes nas décadas de ig60 e I970, período em que as mães dessas garotas davam início a família e casamento. Em uma das falas destacadas por Bordo, manter-se delgada é tido como um modo de evitar a sexualidade, de se tornar "andrógina"; outra entrevistada associa seu pavor em ganhar peso com o desejo de não querer ser "uma tentação para homens" (Bordo, I993: 233). 
Por fim, La cerda punk expõe também tensões no interior do campo feminista, as quais refletem disputas acerca do próprio sentido do fazer político. $\mathrm{Na}$ visão da autora, o feminismo que defende a autonomia sobre o corpo seria falho se não diz respeito também ao que colocamos para dentro por meio da ingestão. Do mesmo modo, seria inconcebível que, "nos círculos feministas mais tradicionais", "utilicemos frases clássicas del feminismo como 'lo personal es político' o 'biologia no es destino' y se ofrezca pan con ave en um seminário de despenalización del aborto" (Castillo, 20I4: I I I).

\section{A TÍTULO DE CONCLUSÃo}

A politização do corpo não é exclusividade do movimento feminista. Se, numa escala variada, inúmeros movimentos sociais politizam o corpo e "incorporam" a política, o corpo é, contudo, um articulador central dos discursos e práticas feministas, tanto no passado quanto no presente (Gomes, 20I7).

Reivindicações demandando o direito ao aborto, ao exercício da sexualidade e a serviços de atenção à saúde da mulher têm sido historicamente enquadradas como parte da luta pela "autonomia das mulheres sobre seus corpos" (Gomes, 20I7). Tendo em mente o fato de que o corpo tenha historicamente se apresentado como um articulador usual no movimento feminista de protesto, é relevante considerar suas particularidades quando se apresenta nas expressões feministas contemporâneas.

Como notado por Gomes (20I7), e reforçado pela presente pesquisa, o corpo tem sido politizado nos discursos e protestos feministas contemporâneos para além do campo dos direitos sexuais e reprodutivos. Enquanto um artefato político central no protesto feminista contemporâneo, o corpo opera não só como um veículo na transmissão de mensagens, mas como a própria mensagem; meio e fim se confundem.

Com o presente texto desenvolvi uma reflexão sobre convenções ligadas a corporalidades no campo feminista jovem, apontando para a estilização de identidades e produção de diferenciações que se dão a partir de uma leitura nativa sobre articulação de marcadores da diferença (gênero, sexualidade, espécie, geração, gordura, raça) e seus efeitos discursivos.

Na produção iconográfica, o corpo é dotado de centralidade; entretanto, não se trata do corpo feminino que é capaz de gestar, entre outras características que tradicionalmente marcariam a "experiência feminina" no mundo. Trata-se de corpos híbridos, que manejam contingencialmente o masculino e o feminino, o animal e o humano, mas também jogam com a gordura, o BDSM, ${ }^{19}$ o trânsito de gênero, a lesbianidade política.

Orientadas pela politização do que é convencionalmente considerado privado, as situações etnográficas acima põem em ação certa desregulação de fronteiras corporais por meio de um regime de (im)permeabilidade com base na interdição vegana, resultando em um reenquadramento dos termos da inteligibi- 
lidade de gênero, espécie e sexualidade. Neste artigo articulei as noções de "tecnologia de gênero", de autoria de Teresa de Lauretis, e as considerações de Judith Butler, entre outras autoras, sobre inscrições corporais e subversões performativas, tendo em mente o que venho sinalizando como pertencimentos ativistas múltiplos e processos de subjetivação.

Tais pontos nodais do campo etnográfico trazem diversas indagações acerca do manejo das fronteiras corporais frente aos efeitos de naturalização das normas de gênero e sexualidade, assim como as possibilidades de agenciamento político intersticiais. Nesse sentido, a politização do privado parece jogar com as "ficções somáticas da feminilidade" (Preciado, 2008) por meio da comida vegana, das produções iconográficas nos fanzines, das performances musicais, das ocupações urbanas, entre outras estratégias de produção, elaboração e "publicização" de diferenças.

Há uso do humor no formato do deboche e da chacota que evidencia a relação crítica com a respeitabilidade e o âmbito institucional. Ainda, é possível apontar para um contexto mais amplo de crítica aos caminhos institucionais de reivindicação formal de direitos, no qual as ativistas lançam mão de estratégias baseadas no faça você mesma e na autonomia feminista, as quais ganham vida em "teias político-comunicacionais" (Alvarez, 20I4a) marcadas por uma série de interlocuções - com a produção teórica e acadêmica, com outros movimentos do campo político feminista e fora dele, com o ativismo realizado nos espaços online, entre outros campos.

Por fim, trata-se de uma discussão que dialoga com produções teóricas recentes que abordam o feminismo e as agências animais por parte de autoras contemporâneas, como o artigo de Beatriz Preciado intitulado "El feminismo no es um humanismo" (2014) ${ }^{20}$ e declarações da teórica e ativista Angela Davis durante a 27th Empowering Women of Color Conference (2014). ${ }^{21}$ Além de trazer contribuições ao debate sobre interseccionalidades, essa discussão aponta também para os limites do estatuto do humano, pondo em questão concepções frequentemente entendidas dentro da chave da racionalidade e da autonomia, como as ideias de sujeito, pessoa e ator social.

Recebido em 20/2/20I7 | Revisto em I0/7/20I7 | Aprovado em 21/8/2017

Íris Nery do Carmo é doutoranda em ciências sociais pela Universidade Estadual de Campinas (Unicamp).

Tem como interesses de pesquisa movimentos sociais, feminismos contemporâneos, gastropolíticas e novos sujeitos políticos. 


\section{NOTAS}

I O presente artigo é parte de pesquisa de doutorado em ciências sociais em desenvolvimento na Universidade Estadual de Campinas (Unicamp), contando com imprescindível financiamento da Fundação de Amparo à Pesquisa do Estado de São Paulo (Fapesp). Agradeço a Regina Facchini, minha orientadora, a interlocução e o estímulo, e aos comentários críticos de Maria Filomena Gregori, Carolina Branco de Castro Ferreira e das pareceristas anônimas da revista Sociologia \& Antropologia. Sou grata também aos colegas da Unicamp e a Alinne Bonetti pela interlocução durante a minha pesquisa de mestrado.

2 Doravante, como convenção para a escrita deste artigo, adoto o recurso gráfico do itálico a fim de marcar termos êmicos, isto é, provindos do trabalho de campo, e estrangeirismos. As aspas serão utilizadas para conceitos e citações.

3 Por exemplo, Carlos Vainer (2013) nota que as manifestações que alteraram o cotidiano das cidades brasileiras em junho de 2013 tomaram "de surpresa" governantes, políticos de todos os partidos, imprensa, cronistas políticos e mesmo cientistas sociais. Também para Raquel Rolnik (2013: I2), esses movimentos, ao propor formas horizontais de decisão, sem personificação de lideranças e sem comando de partidos políticos e comitês centrais, geraram parte da "surpresa" encontrada nas ruas: "onde estão as bandeiras e os carros de som com os megafones? Quem são os líderes? Quem manda?".

4 O termo "autonomia" tem história: foi invocado outrora por feministas no Brasil durante o período ditatorial, a fim de demarcar uma posição externa a partidos políticos e organizações revolucionárias de esquerda. Seus usos remetem também aos anos I990, quando a autonomia emerge mais uma vez no campo, sendo polarizada à categoria acusatória "feministas institucionais" (Alvarez, 20I4a; I998). Autonomia, portanto, não encerra um significado a priori. Um dos objetivos aqui consiste em mostrar seus significados em ação nos eventos e documentos, sem perder de vista sua historicidade.

5 Além de Camargo (20II), são relevantes os trabalhos sobre fanzines realizados por Marques (2016) e Melo (2013). 
6 Mais informações estão disponíveis em <https://monstrans.noblogs.org/sapatoons-queerdrinhos/>. Acesso em 3I out. 2017.

7 Esse evento foi o "DeGeneradas", ocorrido em 2015 no Sesc-Santana na cidade de São Paulo (Diário de campo, 20I5).

8 Em uma relação de oposição a trans, cisgênero é uma categoria êmica empregada para designar pessoas cuja identidade de gênero é entendida como em coerência com o sexo o qual lhe foi designado ao nascer.

9 Reivindicado como símbolo lésbico e representado por um machado de lâmina dupla, o labrys é associado a "várias divindades femininas da mitologia greco-romana, como Gaia, Réa, Ártemis, Diana e aparece também em outros lugares do mundo, como na Índia e no Egito." Disponível em <http://www.tanianavarroswain.com.br/labrys/labrys 3/labrysbr.html>. Acesso em 2 jul. 2013.

Io Gomes \& Sorj (20I4) exploram mais detidamente tais mecanismos de exclusão a partir de elucidativo caso ocorrido na Marcha das Vadias em Brasília (DF).

I I Durante o mestrado, a partir da categoria analítica gastropolítica (Appadurai, I98I), me propus a pensar o veganismo para além de uma interdição alimentar (no caso, uma interdição de alimentos de origem animal) e busquei pensá-lo em seus aspectos produtivos, isto é, quais são os valores a ele atribuídos? Que tipo de corporalidade e estilos ele constrói? Que gastropolítica o engendra? Como o veganismo é encarnado nos discursos e práticas ativistas?

I2 Disponível em <http://www.fazendogenero.ufsc.br/Io/>. Acesso em I4 fev. 2017.

I3 Para uma análise sobre a Marcha das Vadias, ver Gomes (20I7) e Gomes \& Sorj (20I4).

I4 É interessante também notar que o "gênero" é aqui entendido em seu sentido binário - o masculino e o feminino como dois polos autoexcludentes - contra o qual seria necessário lutar. Daí o uso de termos como "(anti)gênero)" e "DeGenerada".

I5 A autora conta que teve conhecimento do zine brasileiro “Gorda, eu?!" durante sua ida ao Encuentro Lesbiintertransfeminista "Venir al sur", realizado no Paraguai em 
20I2, o que indica a extensão latino-americana da rede, bem como o descentramento do sujeito e dos tradicionais Encontros Feministas Latinoamericanos e do Caribe (Eflac).

I6 Disponível em <https://www.facebook.com/motim302/>. Acesso em 25 jan. 2017.

I7 Okupa: termo êmico que alude a "ocupações ilegais anarquistas de casas ou edifícios" (Arruda, 2015: 23I).

I8 Para mais informação sobre o trabalho de Lino Arruda, ver Arruda (20I5).

I9 O acrônimo remete a um conjunto diversificado de práticas eróticas agrupadas sob os termos bondage, disciplina, dominação, submissão, sadismo e masoquismo.

20 Disponível em <http://www.elestadomental.com/revistas/ num5/el-feminismo-no-es-un-humanismo>. Acesso em 23 mar. 2015.

2 I Disponível em <http://www.counterpunch.org/20I4/oI/24/ vegan-angela-davis-connects-human-and-animal-liberation/>. Acesso em 23 mar. 2015.

\section{REFERÊNCIAS BIBLIOGRÁFICAS}

Abonizio, Juliana. (20I6). Conflitos à mesa: vegetarianos, consumo e identidade. Revista Brasileira de Ciências Sociais, 3I/90, p. II5-I37.

Adams, Carol. (2012). A política sexual da carne: a relação entre carnivorismo e a dominância masculina. São Paulo: Alaúde.

Adrião, Karla \& Toneli, Maria. (2008). Por uma política de acesso aos direitos das mulheres: sujeitos feministas em disputa no contexto brasileiro. Psicologia \& Sociedade, 20/3, p. 465-474.

Adrião, Karla; Toneli, Maria \& Maluf, Sônia. (20II). O movimento feminista brasileiro na virada do século XX: reflexões sobre sujeitos políticos na interface com as noções de democracia e autonomia. Estudos Feministas, Florianópolis, I9/3, p. 66I-68I.

Alvarez, Sonia. (20I4a). Para além da sociedade civil: reflexões sobre o campo feminista. Cadernos Pagu, 43, p. I3-56. 
Alvarez, Sonia. (2014b). Engajamentos ambivalentes, efeitos paradoxais: movimentos feminista e de mulheres na América Latina e/em/contra o desenvolvimento. Revista Feminismos, 2/I, p. 57-77.

Alvarez, Sonia. (1998). Feminismos latino-americanos. Estudos Feministas, Florianópolis, 2/6, p. 265-284.

Appadurai, Arjun. (198I). Gastro-politics in Hindu South Asia. American Ethnologist, 8/3, Symbolism and Cognition, p. 494-5II.

Arruda, Lin. (2015). Translesbianizando o olhar: representações na margem da arte. Estudos Feministas, Florianópolis, 23/I, p. 229-238.

Bordo, Susan. (1993). Unbearable weight: feminism, western culture and the body. Berkeley: University of California Press.

Butler, Judith. (2010). Corpos que pesam: sobre os limites discursivos do "sexo". In: Louro, Guacira (org.). O corpo educado: pedagogias da sexualidade. Belo Horizonte: Autêntica, p. I5I-I72.

Butler, Judith. (2003). Problemas de gênero: feminismo e subversão da identidade. Rio de Janeiro: Civilização Brasileira. Camargo, Michelle. (20II). "Manifeste-se, faça um zine!": uma etnografia sobre "zines de papel" feministas produzidos por minas do rock. (São Paulo, I996-2007). Cadernos Pagu, 36, p. I55-I86.

Carmo, Íris Nery do. (20I6a). Múltiplos ativismos: coletivos feministas e os desafios contemporâneos. In: Ferreira, Fabiane \& Bonetti, Alinne (orgs.). Gênero, interseccionalidades e feminismos: desafios contemporâneos para a educação. São Leopoldo: Oikos, p. 63-73.

Carmo, Íris Nery do. (20I6b). "Fiz do meu corpo a revolução": gastropolíticas e contestações de gênero, sexualidade e espécie. In: Colling, Leandro (org.). Dissidências sexuais e de gênero. Salvador: Edufba, p. 91-Io8.

Carmo, Íris Nery do. (2013). "Viva o feminismo vegano!": gastropolítica e convenções de gênero, sexualidade e espécie entre feministas jovens. Dissertação de Mestrado. PPGNEIM/ Universidade Federal da Bahia. 
Castillo, Constanzx. (20I4). La cerda punk: ensayos desde un feminismo gordo, lésbiko, anticapitalista y antiespecista. Valparaiso: Trio Editorial.

Coelho, Maria \& Victora, Ceres. (2017). O corpo que incomoda? Movimentos sociais, corpo e autoridade. Sexualidad, Salud y Sociedad, Rio de Janeiro, 25, p. I56-165.

De Lauretis, Teresa. (I994). A tecnologia do gênero. In: Hollanda, Heloisa (org.). Tendências e impasses: o feminismo como crítica da cultura. Rio de Janeiro: Rocco, p. 206-242.

Díaz, Alejandra. (2017). Hacia la búsqueda de vidas vivibles. El caso de las Feministes Indignades en Barcelona. Estudos Feministas, Florianópolis, 25/I, p. 5I-72.

Facchini, Regina. (2005). Sopa de letrinhas? Movimento homossexual e produção de identidades coletivas nos anos 9o. Rio de Janeiro: Garamond.

Facchini, Regina \& Rodrigues, Julian. (no prelo). "Que onda é essa?": "guerras culturais" e movimento LGBT no cenário brasileiro contemporâneo. In: Viana, Frederico Machado (org.). Entre as ruas e as políticas públicas. Porto Alegre: Editora Rede Unida/Nuances.

Fausto-Sterling, Anne. (200I). Dualismos em duelo. Cadernos Pagu, I7-I8, p. 9-79.

Flores, Valeria. (2014). Prologo. La cerda punk: ensayos desde un feminismo gordo, lésbiko, anticapitalista y antiespecista. Valparaiso: Trio Editorial.

Gomes, Carla de Castro. (20I7). Corpo e emoção no protesto feminista: a Marcha das Vadias do Rio de Janeiro. Sexualidad, salud y sociedad, 25, p. 23I-255.

Gomes, Carla de Castro. (20I6). Nossos corpos, nossos manifestos. Revista Cult, São Paulo. Dossiê "A quarta onda do feminismo", p. 40-43.

Gomes, Carla de Castro \& Sorj, Bila. (20I4). Corpo, geração e identidade: a Marcha das Vadias no Brasil. Sociedade e Estado, 29/2, p. 433-447.

Gonçalves, Eliane. (20I6). Renovar, inovar, rejuvenescer: processos de transmissão, formação e permanência no feminismo brasileiro entre I980-2010. Revista Brasileira de Sociologia, 4/7, p. 34I-370. 
Gonçalves, Eliane; Freitas, Fátima \& Oliveira, Elismênia. (2013). Das idades transitórias: as "jovens" no feminismo brasileiro contemporâneo, suas ações e seus dilemas. Revista Feminismos, I/3.

Gregori, Maria Filomena. (1993). Cenas e queixas: um estudo sobre mulheres, relações violentas e a prática feminista. Rio de Janeiro: Paz e Terra.

Hall, Stuart. (2000). Quem precisa da identidade? In: Silva, Tomaz Tadeu da (org.) Identidade e diferença. Petrópolis: Vozes, p. I03-Із3.

Haraway, Donna. (2009). Manifesto ciborgue: ciência, tecnologia e feminismo-socialista no final do século XX. In: Tadeu, Tomaz (org.). Antropologia do ciborgue: as vertigens do pós-humano. Belo Horizonte: Autêntica.

Kempson, Michelle. (2015). 'My version of feminism': subjectivitiy, DIY and the feminist zine. Social Movement Studies, I4/4, p. 459-472.

MacRae, Edward. (I990). A construção da igualdade: identidade sexual e política no Brasil da "Abertura". Campinas: Ed. Unicamp.

Marques, Gabriela. (20I6). Cena anarcopunk: resistências feministas em um "espaço masculino" (I990-2012). Tese de Doutorado. PPGH/Universidade Federal de Santa Catarina. Matos, Marlise. (20I4). A quarta onda feminista e o campo crítico-emancipatório das diferenças no Brasil: entre a destradicionalização social e o neoconservadorismo político. Anais do 38 Encontro Anual da Anpocs, Caxambu. Melo, Érica de. (2013). O feminismo não morreu - as riot grrrls em São Paulo. Revista Artemis, XV/I, p. I6I-I78.

Oliveira, Elismênia \& Gonçalves, Eliane. (2016). Juventude e feminismo no Brasil: a experiência como lugar de enunciação. In: Scott, Parry; Lyra, Jorge \& Fonte, Isolda (orgs.). Relações e hierarquias marcadas por gênero. Recife: Ed. UFPE, p. 245-262.

Oliveira, João Manuel. (2010). Os feminismos habitam espaços hifenizados - a localização e interseccionalidade dos saberes feministas. Ex Aequo, Lisboa, 22, p. 25-39.

Preciado, Beatriz. (2008). Farmacopoder. In: Testo Yonqui. Madri: Espasa, p. III-I59. 
Preciado, Paul B. (20I4). El feminismo no es un humanismo. Disponível em <https://elestadomental.com/revistas/ num5/el-feminismo-no-es-un-humanismo>. Acesso em 8 jul. 2017.

Ribeiro, Jéssika; Costa, Jussara \& Santiago, Idalina. (2012). Um jeito diferente e "novo" de ser feminista: em cena, o Riot Grrrl. Revista Artemis, I3, p. 222-240.

Rolnik, Raquel. (2013). Apresentação - As vozes das ruas: as revoltas de junho e suas interpretações. In: Maricato, E. et al. Cidades rebeldes: passe livre e as manifestações que tomaram as ruas do Brasil. São Paulo: Boitempo, p. 7-I2. Santos, Magda Guadalupe dos. (2016). Os feminismos e suas ondas. Revista Cult, São Paulo. Dossiê "A quarta onda do feminismo", p. 32-35.

Tobin, Jeffrey. (I999). A performance da masculinidade portenha no churrasco. Cadernos Pagu, I2, p. 301-329.

Vainer, Carlos. (2013). Quando a cidade vai às ruas. In: Maricato, E. et al. Cidades rebeldes: passe livre e as manifestações que tomaram as ruas do Brasil. São Paulo: Boitempo, p. 35-40. 


\section{O PERIGO DAS DOBRAS: ICONOGRAFIAS E CORPORALIDADES NO FEMINISMO CONTEMPORÂNEO}

\begin{abstract}
Resumo
Tendo como tema os movimentos sociais contemporâneos e a produção de sujeitos políticos, a pesquisa de que resulta este artigo analisa o trânsito entre ativismos e o múltiplo pertencimento político a fim de entender a chamada "hifenização" dos feminismos. De cunho etnográfico, a investigação tem como objeto empírico uma rede informal de ativistas que se reconhecem como feministas, têm entre 20 e 30 anos de idade, estão na universidade e provêm de camadas médias urbanas. Elas se apropriam de referências diversas, como o vegetarianismo, o autonomismo, o punk, o direito à cidade, e o anarquismo, tecendo interlocuções e articulações com outras pautas de luta além do gênero. O artigo observa como esses trânsitos são encarnados e tomam corpo no ativismo, por meio de uma análise documental voltada para a produção iconográfica de fanzines, cartazes e documentos de campo.
\end{abstract}

\section{THE DANGER OF FOLDS: ICONOGRAPHIES AND CORPORALITY IN CONTEMPORARY FEMINISM}

\begin{abstract}
This research approaches the contemporary social movements and the emergence of new political subjects. Specifically, it explores the multiple political belongings of activists and their circulation in order to understand the so-called 'hyphenation' of feminisms. Based in major Brazilian cities, this research was undertaken among an informal network of young activists who self-identify as feminists. These are women in their twenties and thirties, from middle-class backgrounds, who have gone to college. They deploy diverse references like vegetarianism/veganism, punk, autonomism and anarchism, making connections with diverse political agendas that extend beyond gender. Adopting an ethnographic approach, the article looks to analyse how these relations are embodied in their iconography of the network's fanzines, flyers and books.
\end{abstract}

Palavras-chave

Corporalidade;

feminismos;

fanzine;

gênero;

sexualidade.
Keywords

Corporality;

feminisms;

fanzine;

gender; sexuality. 